\title{
KUALITAS PELAYANAN PEMBUATAN SURAT IZIN MENGEMUDI (SIM) ONLINE DI POLRES SLEMAN
}

\author{
Tri Wakhyuni, Syakdiah, Retno Kusumawiranti \\ Syakdiyah8@gmail.com \\ Prodi Administrasi Publik Fakultas Ilmu Sosial dan Ilmu Politik \\ Universitas Widya Mataram
}

\begin{abstract}
The SIM Online service is a program launched by the Indonesian National Police through the National Police Priority Program, namely Promoter. One of them from the program is information technology based services. Sleman Police Resort is one of the Polres being a pilot project in the DIY Regional Police jurisdiction in conducting Online SIM Services which is supported by the SIM Implementation Unit (Satpas). The delivery of public services must meet the service quality requirements in accordance with the objectives of the program. To measure service quality, the authors use service quality indicators, namely reliability (reliability), responsiveness (responsiveness), assurance (assurance), empathy (empathy), and physical evidence (tangible).

This study aims to examine and describe the quality of service making Online Driving License (SIM) at the Sleman Police Resort. The research method used is descriptive qualitative. Data collection techniques used were interviews, observation and documentation. Qualitative data analysis techniques are used to analyze the research data.

Based on the results of the study, it was obtained that to measure the quality of Online SIM services at the Sleman Police Satpas using 5 (five) dimensions of service quality as follows; First, the Reliabilty dimension, has not been supported by all human resources who have competency certification in managing SIM Online, but there are already Standard Operating Procedures (SOPs) in the SIM Online service. Second, the Responsiveness dimension, the existence of a fast standard time in SIM extension only requires 15 minutes and for a New SIM requires between 75 minutes to 90 minutes according to the type of SIM. In addition to speed, the service is carried out appropriately with the existence of clear costs based on PP No. 60 of 2016. Third, the dimension of Assurance, the knowledge and abilities of Satpas officers in the SIM Online service. Constraints faced in providing online SIM service guarantees are difficult practice exams and many do not pass. Fourth, Empathy dimension, there is full attention and firmness in the presence of queue numbers and arrangements without any favoritism and discrimination in service in SIM Online services. Fifth, Tangible dimension, there is a Satpas building that has not been used optimally because it has only been used for practical tests, internet networks that are often down and offline, and the number of computers and other devices that are not yet proportional to the large number of people in the SIM Online service. While the information media and waiting room are good and complete.
\end{abstract}

From these results it can be concluded that based on 5 (five) dimensions of service quality, in general it has gone well, but there are some things that need to be improved, such as the quality of human resources, optimization of Satpas buildings, addition of internet network bandwidth, addition of computers and review of regulations about practice exams.

Key words : public services, online driving license (SIM online)

\section{PENDAHULUAN}

Pelayanan publik merupakan salah satu tugas pokok aparatur pemerintahan sebagai abdi masyarakat dalam bentuk jasa pelayanan, baik dalam barang publik maupun jasa publik yang pada prinsipnya menjadi tanggung jawab dan dilaksanakan 
oleh Instansi Pemerintah di Pusat, di Daerah, dan di lingkungan Badan Usaha Milik Negara atau Badan Usaha Milik Daerah, dalam rangka upaya pemenuhan kebutuhan masyarakat maupun dalam rangka pelaksanaan ketentuan peraturan perundang-undangan.

Pemerintah sebagai service provider (penyedia jasa) bagi masyarakat dituntut untuk memberikan pelayanan yang berkualitas. Apalagi pada era teknologi dan informasi yang semakin pesat, kualitas dari pelayanan aparatur pemerintah akan semakin ditantang untuk lebih optimal, kompeten dan mampu menjawab tuntutan yang semakin tinggi dari masyarakat, baik dari segi kuantitas maupun dari segi kualitas. Pelayanan publik yang berkualitas merupakan pelayanan yang mampu memberikan kepuasan kepada masyarakat.

Undang-Undang Republik Indonesia Nomor 25 tahun 2009 tentang Pelayanan Publik pada Pasal 1 huruf (1) menyebutkan definisi pelayanan publik adalah kegiatan atau rangkaian kegiatan dalam rangka pemenuhan kebutuhan pelayanan sesuai dengan peraturan perundang-undangan bagi setiap warga negara dan penduduk atas barang, jasa, dan/atau pelayanan administratif yang disediakan oleh penyelenggara pelayanan publik.

Kepolisian Republik Indonesia
(Polri) merupakan bagian fungs
pemerintahan Negara di bidang
pemeliharaan dan keamanan dan
ketertiban masyarakat, penegak hukum, perlindungan, pengayom, dan pelayanan pada masyarakat. Tugas-tugas tersebut berkaitan erat dengan tugas-tugas sosial yang sehari-harinya berhadapan dengan masyarakat. Secara tidak langsung dapat dikatakan bahwa, Polri sangat erat dengan pelayanan publik.

Pelayanan SIM merupakan salah satu pelayanan dasar administratif yang penting. Dengan SIM, seseorang dianggap sudah memiliki hak dan kewajiban dalam mengendarai kendaran bermotor. Dengan adanya SIM, seseorang telah dianggap menjadi suatu wajib hukum yang taat hukum, sehingga dalam berkendara haruslah selalu mentaati peraturan yang berlaku, SIM merupakan bukti administratif bahwa seseorang tersebut sudah terikat oleh hukum, terutama hukum dalam berkendaraan. Dalam Peraturan Kepala Kepolisian Negara Republik Indonesia Nomer 9 Tahun 2012 Pasal 52 Ayat 2 Tentang Surat Izin Mengemudi. Menyebutkan bahwa yang berwenang dalam melakukan penerbitan SIM kepada masyarakat adalah Kepala Kepolisian di setiap wilayah masing-masing dan didelegasikan kepada Kepala Satuan Lalu Lintas.

Sebagai upaya meningkatkan pelayanan publik, Polri bertekad untuk terus melakukan reformasi birokrasi yang lebih maju dan modern sesuai dengan pesatnya perkembangan teknologi informasi yang sudah menjadi bagian dari kehidupan masyarakat. Hal tersebut ditunjukkan dengan dicanangkan Program Prioritas Kapolri yaitu Promoter yang dijabarkan melalui 11 Program Prioritas Promoter. Isi program yang telah ditetapkan adalah (1) Pemantapan reformasi internal Polri, (2) Peningkatan pelayanan publik yang lebih mudah bagi masyarakat berbasis Teknologi Informasi (TI), (3) Penanganan kelompok radikal prokekerasan dan intoleransi yang lebih optimal, (4) Peningkatan profesionalisme Polri menuju keunggulan, (5) Peningkatan kesejahteraan anggota Polri, (6) Tata kelembagaan, pemenuhan proporsionalitas anggaran dan kebutuhan minimum sarpras, (7) Membangun kesadaran dan partisipasi masyarakat terhadap kamtibnas, (8) Penguatan harkamtibnas (pemeliharaan keamanan dan ketertiban), (9) Penegakkan hukum yang lebih profesional dan berkeadilan, (10) Penguatan pengawasan, (11) Quick Wins Polri, (sumber: http://promoter.polri.go.id/landing/,

diakses tanggal 3 Maret 2019).

Program Promoter Kapolri nomor 2

yakni "Peningkatan pelayanan publik yang lebih mudah bagi masyarakat berbasis Teknologi Informasi (TI)" menjadi cara bagi organisasi kepolisian berlomba-lomba untuk memaksimalkan kinerja dan mempertahankan eksistensi Polri dalam memberikan pelayanan kepada masyarakat dengan membuat terobosan kreatif dan inovasi-inovasi dalam bidang Teknologi Informasi. 
Terdapat 45 Satpas SIM diseluruh Indonesia yang terintegrasi SIM Online, salah satunya di Polres Sleman yang merupakan bagian dari Kepolisian Daerah (Polda) Daerah Istimewa Yogyakarta (DIY) yang mengemban tugas sebagai "Pilot Project" pembuatan SIM Online di wilayah hukum Polda DIY. SIM Online adalah layanan Perpanjangan SIM dimana database Satpas diseluruh Indonesia (yang sudah Online) saling terhubung antar jaringan. Datanya mengambil data identitas KTP Elektronik masyarakat. Pendaftaranya bisa dilakukan secara Online melalui website Korlantas Polri sehingga tidak perlu mengisi formulir lagi seperti saat membuat SIM di Satpas. (Tribunjogja.com: Rabu, 23 Januari 2019, diaksea tanggal 3 Maret 2019).

Penerapan Surat Izin Mengemudi (SIM) Online adalah sebagai implementasi dan bentuk upaya peningkatan kualitas pelayanan Polri di bidang penerbitan SIM kepada masyarakat. Selain itu, pelaksanaan Surat Ijin Mengemudi (SIM) Online sebagai bentuk upaya untuk membangun dan melaksanakan pelayanan prima kepada masyarakat di bidang regident SIM guna terciptanya zero complain, bebas korupsi dan terciptanya birokrasi bersih di lingkungan Polres Sleman pada khususnya.

Berdasarkan hasil observasi pra penelitian yang dilakukan peneliti, bahwa Polres Sleman sejak tahun 2018 menjadi pilot project pelayanan SIM Online. Keberadaan pelayanan SIM Online tersebut memberikan kemudahan kepada masyarakat, baik membuat SIM baru maupun perpanjangan. Program tersebut direspon positif oleh warga masyarakat yang membutuhkan pelayanan SIM.

Tabel 1

Rekapitulasi Jumlah Pelayanan SIM Online Di Polres Sleman Tahun 2018

\begin{tabular}{|c|c|c|c|c|}
\hline \multirow{2}{*}{ BULAN } & \multicolumn{2}{|c|}{ SIM BARU } & \multicolumn{2}{c|}{ PERPANJANGAN } \\
\cline { 2 - 5 } & $\mathrm{A}$ & $\mathrm{C}$ & $\mathrm{A}$ & $\mathrm{C}$ \\
\hline JANUARI & 1.356 & 1.613 & 1.464 & 3.515 \\
\hline FEBRUARII & 880 & 1.588 & 1.315 & 2.650 \\
\hline MARET & 668 & 1.184 & 1.425 & 2.697 \\
\hline APRIL & 721 & 1.095 & 1.294 & 2.841 \\
\hline MEI & 892 & 1.355 & 1.638 & 3.712 \\
\hline JUN & 791 & 1.143 & 1.661 & 3.375 \\
\hline JULI & 1.261 & 2.050 & 1.524 & 3.884 \\
\hline AGUSTUS & 582 & 1.034 & 1.661 & 4.174 \\
\hline SEPTEMBER & 544 & 1.081 & 1.412 & 3.126 \\
\hline OKTOBER & 831 & 1.519 & 1.291 & 2.912 \\
\hline NOVEMBER & 968 & 1.773 & 1.284 & 3.117 \\
\hline DESEMBER & 785 & 1.221 & 1.146 & 2.832 \\
\hline & $\mathbf{1 0 . 2 7 9}$ & $\mathbf{1 6 . 6 5 6}$ & $\mathbf{1 7 . 1 1 5}$ & $\mathbf{3 8 . 8 3 5}$ \\
\hline
\end{tabular}

Sumber : Sat. Lantas Polres Sleman (2019) 
Dari tabel di atas menunjukkan bahwa jumlah pelayanan SIM Online di Polres Sleman dari kelompok masyarakat yang membuat SIM baru selama Tahun 2018 untuk SIM A sebanyak 10.279 orang dan SM C sebanyak 16.656 orang, sedangkan kelompok perpanjangan SIM A sebanyak 17.115 orang dan SIM C sebanyak 38.835 orang. Namun demikian, tingginya animo masyarakat belum didukung oleh sarana dan prasarana serta fasilitas yang memadai, seperti jumlah dan kualitas komputer yang masih belum memadai, server SIM Online sering mengalami offline di karenakan jaringan internet yang tidak stabil. Menurut peneliti, seharusnya tingginya animo masyarakat dalam pelayanan pembuatan SIM Online didukung dengan sarana prasarana serta fasilitas pendukung yang lebih modern dan akses internet yang lebih cepat.

Pelayanan dalam pembuatan SIM Online menjadi salah satu dasar penilaian kinerja kepolisian yang paling kasat mata. Masyarakat dapat langsung menilai kinerja Kepolisian berdasarkan kualitas layanan yang diterima, dimana keberhasilan dalam membangun kinerja pelayanan publik secara profesional, transparan, dan akuntabel akan mengangkat citra Polri di mata masyarakat.

\section{Konsep Pelayanan Publik}

Istilah pelayanan dalam bahasa Inggris adalah "service". H.A.S. Moenir (2008:26-27) mendefinisikan "pelayanan sebagai kegiatan yang dilakukan oleh seseorang atau sekelompok orang dengan landasan tertentu dimana tingkat pemuasannya hanya dapat dirasakan oleh orang yang melayani atau dilayani, tergantung kepada kemampuan penyedia jasa dalam memenuhi harapan pengguna.

Pelayanan publik secara sederhana dipahami oleh berbagai pihak sebagai pelayanan yang diselenggarakan oleh pemerintah. Semua barang dan jasa yang diselenggarakan oleh pemerintah kemudian disebut sebagai pelayanan publik. (Dwiyanto, 2015: 14). Selanjutnya pendapat lain menyatakan bahwa pelayanan publik adalah segala kegiatan pelayanan yang dilaksanakan oleh penyelenggara pelayanan publik sebagai upaya pemenuhan kebutuhan publik dan pelaksanaan ketentuan peraturan perundangundangan. (Mahmudi, 2010: 22).

Di dalam Undang-Undang Nomor 25 Tahun 2009 tentang Pelayanan Publik, mendefinisakan bahwa pelayanan publik adalah kegiatan atau serangkaian kegiatan dalam rangka pemenuhan kebutuhan pelayanan sesuai dengan peraturan perundangundangan bagi setiap warga negara dan penduduk atas barang, jasa, dan atau pelayanan administratif yang disediakan oleh penyelenggara pelayanan publik.

Berdasarkan beberapa pengertian di atas, dapat disimpulkan bahwa pelayanan publik merupakan pelayanan yang dapat memenuhi kebutuhan masyarakat sesuai dengan hak-hak atas suatu barang, jasa dan pelayanan admisnistrasi yang dilaksanakan oleh penyelenggara pelayanan seperti lembaga pemerintahan yang menyelenggarakan pelayanan publik, sesuai dengan undangundang yang telah ditetapkan.

Dalam proses kegiatan pelayanan publik terdapat beberapa faktor atau unsur yang mendukung jalannya kegiatan. Unsurunsur pelayanan publik tidak dapat dipisahkan satu dengan yang lainnya karena keempatnya akan membentuk proses kegiatan (activity). Menurut H.A.S. Moenir (2008: 186) unsurunsur pelayanan publik terdiri dari sebagai berikut:

1) Tugas layanan

2) Sistem atau prosedur layanan

3) Kegiatan pelayanan

4) Pelaksana pelayanan

Sedangkan menurut Barata (2014:11), terdapat empat unsur penting dalam proses pelayanan publik, yaitu:

1) Penyediaan layanan.

2) Penerima layanan.

3) Jenis layanan.

4) Kepuasan pelanggan.

Menurut Ratminto dan Winarsih (2006:245), terdapat beberapa asas dalam penyelengaraan pelayanan pemerintah yang harus diperhatikan sebagai berikut :

1) Empati dengan customers.

2) Pembatasan prosedur.

3) Kejelasan tata cara pelayanan.

4) Minimalis persyaratan pelayanan.

5) Kejelasan kewewenangan.

6) Transparasi biaya.

7) Kepastian jadwal dan durasi pelayanan.

8) Minimalis formulir.

9) Memaksimalisasi masa berlakunya izin.

10) Efektivitas penanganan keluhan pelayanan yang baik sedapat 
mungkin harus menghindarkan terjadinya keluhan, akan tetapi jika muncul keluhan maka harus dirancang suatu mekanisme yang dapat memastikan bahwa keluhanan tersebut akan diganti secara efektif sehingga permasalahan yang ada dapat segera diselesaikan.

Menurut Keputusan Menteri Pemberdayaan Aparatur Negara No. 63 Tahun 2003 Tentang Pedoman Umum Penyelenggaraan Pelayanan Publik, standar pelayanan haruslah meliputi:

1) Prosedur Pelayanan

2) Waktu Penyelesaian

3) Biaya Pelayanan

4) Produk Pelayanan

5) Sarana dan Prasarana.

Kualitas pelayanan (service quality) telah hampir menjadi faktor yang menetukan dalam menjaga keberlangsungan suatu organisasi birokrasi pemerintah maupun organisasi perusahaan. Kualitas pelayanan yang baik dan sesuai dengan kebutuhan pengguna jasa publik, sangat penting dalam upaya mewujudkan kepuasan pengguna jasa publik (customer satisfaction). Menurut Sinambela (2011: 6) kualitas pelayanan adalah segala sesuatu yang mampu memenuhi keinginan atau kebutuhan pelanggan (meeting the needs of customers). Sedangkan menurut Kasmir dalam Pasolong (2011:133) mengatakan bahwa pelayanan yang baik adalah kemampuan seseorang dalam memberikan pelayanan yang dapat memberikan kepuasan kepada pelanggan dengan standar yang telah ditentukan.

Menurut Zauhar (2007: 22), kualitas pelayanan adalah penyesuaian terhadap perincian-perincian (conformance to specification) dimana kualitas ini dipandang sebagai derajad keunggulan yang ingin dicapai, dilakukannya kontrol terus menerus dalam mencapai keunggulan tersebut dalam rangka memenuhi kebutuhan pengguna jasa. Pelayanan merupakan respon terhadap kebutuhan manajerial yang hanya terpenuhi jika pengguna jasa itu mendapatkan produk yang mereka inginkan. Selanjutnya menurut Goetsch dan Davis dalam Hardiyansyah (2011:36), menyatakan bahwa kualitas pelayanan adalah sesuatu yang berhubungan dengan terpenuhinya harapan/kebutuhan pelanggan, dimana pelayanan dikatakan berkualitas apabila dapat menyediakan produk dan jasa (pelayanan) sesuai dengan kebutuhan dan harapan pelanggan. Dalam hal ini, kualitas pada dasarnya terkait dengan pelayanan yang baik, yaitu sikap atau cara karyawan dalam melayani pelanggan atau masyarakat secara memuaskan.

Tingkat kepuasan seorang pelanggan dapat dilihat dari nilai produk atau jasa yang diberikan oleh instansi penyelenggara pelayanan kepada pelanggan. Kebutuhan pelanggan terhadap produk atau jasa bermacam-macam bentuknya. Tugas Instansi Pemerintah sebagai penyelenggara dan pemberi pelayanan produk atau jasa kepada masyarakat harus memberikan pelayanannya secara optimal agar terwujud kualiatas pelayanan yang baik.

Ada beberapa pendapat mengenai pengukuran kualitas pelayanan, antara lain Parasuraman, Zeithaml, dan Berry dalam Saleh (2010:103) yang melakukan penelitian khusus terhadap beberapa jenis jasa dan berhasil mengidentifikasi sepuluh faktor utama yang menentukan kualitas jasa. Pada perkembangan selanjutnya, Zeithaml, dkk. (dalam Gregorius Chandra, dkk., 2011:198), menyederhanakan sepuluh dimensi pengukuran kualitas pelayanan di atas menjadi lima dimensi pokok yang dikenal dengan SERQUAL (service quality) yang terdiri dari:

a. Reliability (kehandalan), yaitu kemampuan untuk memberikan pelayanan yang diinginkan dengan segera, akurat dan memuaskan. Kinerja harus sesuai dengan harapan pelanggan yang berarti ketepatan waktu, pelayanan yang sama untuk semua pelanggan tanpa ada kesalahan, sikap simpatik dan akurasi yang tinggi.

b. Responsiveness (daya tanggap), yaitu kemampuan perusahaan untuk membantu dan memberikan pelayanan yang cepat (responsif) dan tepat kepada para pelanggan dengan penyampaian informasi yang jelas. Membiarkan pelanggan menunggu tanpa ada suatu alasan yang jelas menyebabkan persepsi yang negatif terhadap kualitas pelayanan.

c. Assurance (jaminan), adanya kepastian yaitu pengetahuan, kesopan santunan dan kemampuan para pegawai untuk menumbuhkan rasa percaya para pelanggan kepada pelayan perusahaan yang memiliki beberapa komponen antara lain: 
d. Empathy (empati), yaitu memberikan perhatian yang tulus dan bersifat individu atau pribadi yang diberikan kepada para pelanggan dengan berupaya memahami keinginan konsumen. Dimana suatu perusahaan diharapkan memiliki suatu pengertian dan pengetahuan tentang pelanggan, memahami kebutuhan pelanggan secara spesifik, serta memiliki waktu pengorganisasian yang nyaman bagi pelanggan.

e. Tangibles (bukti fisik), yaitu kemampuan suatu perusahaan dalam menunjukkan eksitensinya kepada pihak eksternal perusahaan. Penampilan dan kemampuan sarana dan prasarana fisik perusahaan dan keadaan lingkungan sekitarnya adalah bukti nyata dari pelayanan yang diberikan pihak perusahaan.

\section{METODE PENELITIAN}

Penelitian in menggunakan metode kualitatif. Penelitian kualitatif mengunakan data deskriptif berupa kata kata tertulis atau lisan dari orang orang dan perikalu yang dapat diamati (Bogdan dan Taylor dalam Sugiyono 2014). Penelitian kualitatif menurut Sugiyono (2005) dalam Pasolong (2013:161) yaitu metode penelitian yang digunakan untuk meneliti pada kondisi objek alamiah, penelitian kualitatif lebih menekankan makna dari pada generalisasi. Metode kualitatif berusaha memahami dan menafsirkan makna suatu peristiwa interaksi tingkah laku manusia dalam situasi tertentu menutur perspektif peneliti sendiri.

Penelitian ini akan mencoba mendalami gejala yang menginterprestasikan masalah nya atau menyimpulkan kombinasi dari berbagai arti permasalahan nya sebagaimana situasi yang tersaji. Penelitian ini digolongkan dalam penelitian deskriptif. Format penelitian deskriptif bertujuan untuk menggambarkan, meringkaskan berbagai kondisi, berbagai situasi atau berbagai variabel yang timbul di masyarakat yang menjadi objek penelitian tersebut (Bungin, 2013:48).

\section{PEMBAHASAN}

Kualitas Pelayanan SIM Online Berdasarkan Dimensi Keandalan (Reliability) yaitu seberapa jauh pelayanan yang diberikan Polres Sleman dalam penyelenggaraan Program SIM Online sesuai dengan tujuannya, yaitu memberikan kemudahan dan menghindari terjadinya kecurangan dalam pengurusan SIM. Keandalan dalam penelitian ini mencakup ketersediaan dan dukungan Sumber Daya Manusia (SDM) yang handal dalam pelayanan sesuai Standar Operasional Presedur (SOP) yang telah dibuat.

Hasil penelitian menunjukkan bahwa tingkat keandalan penyelenggaraan SIM Online Polres Sleman di dukung oleh SDM atau petugas Bagian SIM di Satuan Penyelenggara Administrasi SIM (Satpas) Polres Sleman dari 17 orang, sebanyak 5 orang sudah bersertifikasi khususnya dibagian teori, identifikasi dan formulir. Dari data tersebut Penulis dapat mengatakan bahwa kualitas SDM Bagian SIM di Satpas Polres Sleman masih harus ditingkatkan lagi karena baru sebagian kecil yang sudah memiliki sertifikasi kompetensi dalam pengelolaan SIM Online. Walaupun demikian, dengan kompetensi personil seperti itu sudah mampu dalam pelayanan SIM Online. Sedangkan dalam hal kualitas petugas Bagian SIM di Satpas Polres Sleman, petugas pengelola SIM Online harus memiliki kualifikasi dan kompetensi khusus. Ditinjau dari segi kualitas SDM di Bagian SIM Polres Sleman masih belum memadai, dari 17 petugas yang ada, baru 5 petugas yang sudah memiliki sertifikasi kompetensi. Upaya Polres Sleman yang sudah dilakukan dalam meningkatkan kualitas petugas Bagian SIM dengan mengikuti pelatihan kompetensi Pengujian SIM atau pendidikan lainnya yang terkait dengan pengelolaan SIM. Selain itu, salah satu indikator keandalan (reliability) dalam memberikan pelayanan SIM Online di Satpas Polres Sleman, adanya Standar Operasional Prosedur (SOP) tentang penyelenggaraan SIM Online, alur dan mekanisme penerbitan SIM Online yang sudah ditentukan dan menjadi SOP dalam pelayanan SIM Online di Satpas Polres Sleman. SOP Penerbitan SIM bertujuan sebagai pedoman standar bagi petugas Polri dalam prosedur pelayanan masyarakat dalam penerbitan SIM dalam rangka terwujudnya efektifitas, efisiensi, dan akuntabilitas setiap tindakan Petugas Satpas Polres Sleman dalam kegiatan pelayanan penerbitan SIM yang meliputi pendaftaran, ujian teori, ujian praktek, produksi SIM, penyerahan, dan pengarsipan dokumen pemohon SIM. Adanya dasar hukum dan alur dan mekanisme penyelenggaraan SIM Online di Satpas Polres Sleman menunjukkan bahwa Program SIM Online yang dilaksanakan sudah sesuai dengan peraturan 
perundang-undangan yang berlaku. SOP tersebut merupakan panduan bagi masyarakat dalam pengurusan SIM, baik itu pembuatan baru, perpanjangan maupun mengurus SIM yang hilang. Dengan adanya SOP tersebut memberikan gambaran tata cara dan persyaratan serta kegiatan dari masing-masing loket dalam penyelenggaraan SIM Online. SOP penyelenggaraan SIM Online di Polres Sleman meliputi beberapa hal, antara lain persyaratan dan alur pelayanan Satpas Polres Sleman. Syarat yang harus dipenuhi oleh masyarakat yang akan mengurus Pembuatan SIM Baru, seperti KTP Asli dan Fotocopy, Surat Keterangan Dokter, dan khusus untuk pembuatan SIM A dan B Surat Keterangan Uji Ketrampilan Pengemudi (SKUKP) dari Dirlantas Polda DIY. Sedangkan syarat untuk perpanjangan dan kehilangan SIM adalah; KTP Asli dan Fotocopy, Surat Keterangan Dokter, dan khusus untuk pembuatan SIM A dan B Surat Keterangan Uji Ketrampilan Pengemudi (SKUKP) dari Dirlantas Polda DIY, dan untuk kehilangan ditambah adanya laporan kehilangan dari Polri. Keandalan yang diberikan terhadap pelayanan SIM Online, ditunjukkan dengan ketersediaan SDM dan sistem yang terbangun dalam pelayanan SIM Online. Selain dukungan SDM didukung pula sistem dan aturan kerja yang jelas dengan adanya SOP pelayanan SIM Online. SOP yang diterapkan di Satpas Polres Sleman meliputi aturan dan prosedur serta mekanisme pelayanan SIM Online dalam bentuk alur proses pelayanan, baik Pelayanan Perpanjangan dan Kehilangan SIM maupun Pembuatan SIM Baru. Dalam SOP juga diatur tentang mekanisme pembuatan SIM Online bagi WNA dengan harus memenuhi persyaratan yang telah ditentukan.

Ketanggapan (Responsiveness) adalah kemampuan memenuhi permintaan warga masyarakat yang mengurus SIM Online dengan cepat dan tepat. Ketanggapan dalam hal ini mencakup antara lain; ketanggapan dan kecepatan respon dari petugas terhadap masyarakat, kesiapan dan kesediaan petugas dalam membantu masyarakat, keramahan dan kejelasan informasi mekanisme pengurusan SIM Online. Berdasarkan hasil penelitian, Satpas Polres Sleman sudah memberikan daya tanggap yang baik dengan cepat, tepat, ramah dan informasi yang jelas. Hal tersebut ditunjukkan beberapa indikator dari dimensi Responsiveness, antara lain, setiap loket terdapat petugas yang menyambut dengan senyum dan menanyakan secara ramah dan sopan tentang keperluan. Petugas juga selalu memberikan informasi dengan menjelaskan alur dan prosedur pengurusan SIM. Sebagian besar petugas yang melayani SIM Online tidak berseragam Polri kecuali di loket-loket tertentu, sehingga dengan tidak memakai seragam Polri memberi kesan lebih ramah dan tidak kaku. Selain itu, informasi-informasi yang terkait dengan pengurusan SIM Online sudah terdapat pada spanduk alur dan mekanisme penerbitan SIM yang ditempel ruangan. Petugas pelayanan yang memiliki daya tanggap yang baik dan ramah dalam memberikan pelayanan adalah aspek penting yang sangat menunjang kinerja pelayanan publik yang baik. Dimensi dalam pelayanan yang responsif adalah kemauan selalu menyapa pengguna layanan dengan ramah senyum dan menawarkan bantuan secara otomatis. Beberapa dimensi pelayanan yang responsif tersebut tentunya sangat didambakan oleh semua pengguna layanan. Salah satu indikator dari dimensi responsiveness dalam penelitian ini adalah kecepatan dan ketepatan. Salah satu ketepatan pelayanan yang diberikan oleh Polres Sleman dalam pelayanan SIM adalah ketepatan dalam penentuan tarif atau biaya. Ketepatan biaya penyelenggaraan SIM Online dengan mengacu pada Peraturan Pemerintah Nomor 60 Tahun 2016 tentang Jenis Dan Tarif Atas Jenis Penerimaan Negara Bukan Pajak Yang Berlaku Pada Kepolisian Negara Republik Indonesia. Keberadaan SOP dalam penyelenggaraan SIM Online di Satpas Polres Sleman mendapat tanggapan yang baik dari warga masyarakat. Tata cara dan sistem yang sudah terbangun dapat menjadikan sebuah program dapat berjalan dengan baik. Begitu juga dalam penyelenggaraan SIM Online di Satpas Polres Sleman, SOP yang ada sudah memberikan kemudahan dan pemahaman kepada masyarakat dalam melalui prosedur dan langkah-langkah pelayanan SIM, sehingga masyarakat tidak merasa bingung dan menjadi korban calo.

Jaminan (Assurance) adalah kemampuan atau sumber daya yang dimiliki untuk kemampuan memenuhi apa yang ditawarkan atau dijanjikan sehingga dapat menimbulkan kepercayaan tanpa menimbulkan karaguan terhadap pelayanan. Dimensi jaminan yang dimaksud dalam penelitian ini adalah adanya ketrampilan dan 
kemampuan petugas dalam melayani masyarakat yang mengurus SIM Online. Sesuai dengan SOP yang diterapkan dalam pelayanan SIM Online, maka ketrampilan dan kemampuan petugas dalam mengoperasikan komputer menjadi salah satu indikator dalam memberikan jaminan pelayanan SIM Online. Selain itu, kemampuan petugas dalam memberikan jawaban atau menjelaskan tentang prosedur dan mekanisme SIM Online menjadi salah satu faktor adanya kepuasan masyarakat. SIM Online merupakan pelayanan berbasis aplikasi dengan internet, sehingga petugas yang memberikan pelayanan tidak hanya mampu dalam mengoperasikan komputer, tetapi mampu memberikan penjelasan tentang menu-menu yang terdapat dalam website http://sim.korlantas.polri.go.id. Kemampuan petugas dalam menguasai komputer dan aplikasi tersebut menjadi salah satu indikator memberikan kepuasan dalam pelayanan SIM Online. Dari 17 petugas Satpas Polres Sleman, berjumlah 5 petugas sudah memiliki sertifikasi kompetensi dalam pengelolaan dan pelayanan SIM Online. Jumlah tersebut memang belum memadai jika dibandingkan dengan jumlah masyarakat yang membutuhkan pelayanan SIM Online, baik itu perpanjangan maupun pembuatan SIM baru. Hasil observasi di lapangan bahwa masyarakat yang memerlukan pelayanan SIM di Satpas Polres Sleman setiap harinya \pm 250 orang. Namun demikian, kualitas pelayanan terus dilakukan dengan menempatkan petugaspetugas yang berpengalaman dengan masa kerja yang sudah lama pada pelayanan SIM sembari berupaya meningkatkan kualitas petugas dengan memberikan pelatihan dan pendidikan pengelolaan SIM. Keramahan dalam memberikan pelayanan menjadi kunci dalam penyelenggaraan Program SIM Online. Keramahan petugas dalam membantu masyarakat dalam pelayanan SIM Online. Petugas mencoba untuk membantu seorang Ibu dengan memangku anak yang dibawanya karena $\mathrm{Si}$ Ibu tersebut akan melakukan registrasi SIM Online.

Empati adalah memberikan perhatian yang tulus dan bersifat individu atau pribadi yang diberikan kepada orang lain dengan berupaya memahami keinginan orang tersebut. Dimensi empati dalam penelitian ini ditunjukan dengan dengan adanya perhatian dan ketegasan petugas Satpas Polres Sleman dalam melayani SIM Online. Setiap warga masyarakat yang datang langsung akan disambut oleh petugas dan menanyakan keperluannya. Setelah itu mengambil nomor antrian untuk tahapan pelayanan SIM Online. Dimensi empati menjadi salah satu indikator kualitas pelayanan SIM Online di Satpas Pores Sleman. Perhatian petugas dalam melayani masyarakat menjadi salah satu wujud empati yang diberikan. Selain itu juga, ketegasan petugas dengan memperlakukan seluruh warga masyarakat dalam pelayanan SIM Online disesuaikan dengan nomor antrian, tidak membeda-bedakan atau pilih kasih dalam memberikan pelayanan. Informasi dan pengaturan yang jelas dalam memberikan pelayanan menjadi hal utama dalam kualitas pelayanan. Petugas Satpas Polres Sleman hingga saat ini telah mengembangkan suatu empati yang ditujukan dalam bentuk kemudahan dalam pelayanan SIM Online, pengertian dan pemahaman petugas terhadap kebutuhan masyarakat dengan memberikan informasi secara jelas tentang prosedur dan mekanisme pelayanan SIM Online, komunikasi yang baik dan ramah dari petugas dalam melayani masyarakat (melayani dengan ekspresi menyenangkan dan tersenyum).

Dimensi bukti fisik (Tangible) adalah kemampuan Satpas Polres Sleman dalam mendukung penyelenggaraan pelayanan SIM Online yang diberikan kepada masyarakat. Penampilan sarana dan prasarana Satpas Polres Sleman dan keadaan lingkungan sekitarnya adalah bukti nyata dari pelayanan yang diberikan oleh penyedia jasa yang meliputi fasilitas fisik tempat pelayanan tersebut, teknologi (komputer dan jaringan internet) serta penampilan pegawai dalam melayani pengguna layanan. Berdasarkan data yang diperoleh di lapangan, Satuan Penyelenggara Administrasi SIM (Satpas) Polres Sleman sudah memiliki gedung baru yang dibangun pada tahun 2018. Gedung Satpas Polres Sleman terdiri dari 3 (tiga) lantai yang kesemuanya difungsikan untuk pelayanan SIM, yaitu lantai 1 digunakan untuk uji paktek kendaraan roda 4, lantai 2 untuk administrasi, dan lantai 3 untuk uji praktek kendaraan roda 2. Satpas Polres Sleman juga merupakan satu-satunya Satpas yang memiliki ruang praktik indoor. Akan tetapi sampai penelitian ini dilakukan, Gedung Satpas Polres Sleman baru digunakan pada lantai 1 dan 3 untuk Ujian Praktik SIM. Sementara untuk lantai 2 belum digunakan pelayanan karena 
terlihat masih kosong dari perangkat dan fasilitas pelayanan Satpas. Bentuk media informasi yang dimiliki oleh Satpas Polres Sleman berupa papan-papan pengumuman atau banner tentang Alur dan Mekanisme Satpas Polres Sleman, alur dan mekanisme pelayanan SIM, baik SIM Baru maupun Perpanjangan, informasi tentang waktu pelayanan, informasi tentang biaya Pelayanan, informasi persyaratan pelayanan SIM Online dan media informasi lainnya, seperti pamflet, website (http://sim.korlantas.polri.go.id.), Call Center Satpas Polres Sleman (0274-2880396), Instagram(@satlantas_sleman), Surat Kabat dan talkshow di radio atau TV lokal. Ketersediaan media informasi tersebut dapat memberikan kemudahan kepada masyarakat untuk mengetahui apa saja langkah-langkah dan prosedur serta persyaratan dalam pelayanan SIM Online. Selain itu informasi langsung oleh petugas terhadap masayarakat di Satpas dapat lebih memberikan pengetahuan dan pemahaman mengenai tahapan pelayanan SIM Online, sehingga masyarakat merasa puas dalam melakukan pelayanan Sim Online di Satpas Polres Sleman. Salah faktor pendukung dalam penyelenggaraan SIM Online adalah komputer. Keberadaan komputer atau laptop menjadi faktor lancarnya penyelenggaraan SIM Online. Selain itu, jaringan internet yang kuat dan stabil. Dikarenakan pelayanan SIM Online selalu menggunakan komputer dan jaringan internet, maka ketersediaan dua fasilitas tersebut sangat penting. Besarnya kapasitas jaringan internet (Bandwidth) dalam pelayanan SIM Online di Polres Sleman sebesar 1 MBps. Satpas Polres Sleman memiliki 1 set perangkat komputer di masingmasing loket dengan petugas yang mengoperasikannya dalam tahapan pelayanan SIM Online. Ruang tunggu yang ada berada di sebelah depan dari masing-masing loket pelayanan. Khsuusnya pada loket pendaftaran pelayanan, runag tunggu dibuat senyaman mungkin yang dilengkapi dengan AC dan tempat duduk (kursi) yang baik, WC. Di ruang tunggu juga tersedia Televisi dan Ruang Bermain Anak agar konsumen dapat menonton dan tempat bermain anak sambil menunggu panggilan.

\section{Kesimpulan}

1. Dimensi Keandalan (Reliability) diukur dengan adanya dukungan Sumber Daya Manusia (SDM) dan Standar Operasional
Prosedur (SOP). SDM petugas pelayanan SIM Online belum memadai karena SDM yang ada sebagian besar belum memiliki sertifikasi kompetensi, yaitu dari 17 petugas Bagian SIM baru 5 petugas yang sudah memiliki sertifikasi kompetensi. Untuk SOP ditunjukkan dengan adanya alur dan mekanisme pelayanan SIM Online, persyaratan pembuatan SIM Baru maupun perpanjangan, standar waktu pelayanan, dan standar biaya pelayanan yang mengacu pada Peraturan Pemerintah.

2. Dimensi Daya Tanggap (Responsiveness) di Satpas Polres Sleman sudah baik. Adanya kecepatan dan ketepatan dalam pelayanan SIM Online. Kecepatan ditunjukkan dengan mengacu kepada SOP waktu pelayanan, dimana untuk perpanjangan hanya memerlukan waktu 15 menit, sedangkan untuk SIM Baru memerlukan waktu antara 75 sampai 90 menit sesuai dengan jenis pelayanan SIM nya. Ketepatan dapat ditunjukkan dengan adanya ketepatan respon petugas yang secara tepat melakukan pendampingan dan memberikan informasi tentang langkah-langkah pelayanan SIM Online. Selain itu, ketepatan dalam penentuan biaya pelayanan sudah sesuai standar yang ditetapkan,

3. Dimensi Jaminan (Assurance) yang diberikan oleh Satpas Polres Sleman sudah baik. Adanya kemampuan dan keramahan petugas dalam pelayanan SIM Online. Kemampuan petugas ditunjukkan dengan kemampuan SDM dalam menguasai teknologi informasi dalam operasional komputer dan pengelolaan website SIM Online dalam setiap loket pelayanan. Sikap ramah dalam pelayanan SIM Online, yang ditunjukkan dengan setiap petugas selalu menyambut dengan senyum terhadap masyarakat yang datang dan memberikan informasi tentang langkah-langkah pelayanan SIM Online. Pakaian yang dipakai oleh petugas pada hari-hari tententu tidak menggunakan pakaian dinas kepolisian. Kendala yang dihadapi dalam memberikan jaminan pelayanan SIM Online adalah Ujian Praktik yang sulit dan banyak yang tidak lulus.

4. Dimensi Empati (Empaty) yang diberikan oleh Satpas Pores Sleman sudah baik dengan adanya perhatian dan ketegasan petugas pada setiap loket. Perhatian petugas ditunjukkan dengan respon cepat petugas 
ketika ada warga masyarakat dalam pelayanan SIM Online yang bingung dan membutuhkan pertolongan, sehingga setiap loket pada tahapan pelayanan SIM Online ditempatkan petugas pendamping. Adanya ketegasan petugas dengan melayani sesuai nomor antrian yang sudah dimiliki. Pelayanan yang tidak pilih kasih dan diskriminasi, sehingga setiap warga masyarakat dalam pelayanan SIM Online di Satpas Polres Sleman dapat dilayanai sesuai aturan yanng sudah ditentukan.

5. Dimensi Bukti Fisik (Tangible) masih belum optimal karena Gedung Satpas Polres Sleman belum digunakan secara optimal. Gedung Satpas yang memiliki 3 lantai baru digunakan lantai 1 dan 3 untuk ujian praktik. Selanjutnya fasilitas jaringan internet yang seringkali down dan off, sehingga pelayanan SIM Online sering terganggu. Fasilitas yang belum memadai dengan jumlah komputer yang belum sebanding dengan banyaknya jumlah masyarakat yang memanfaatkan pelayanan SIM Online. Namun ada beberapa fasilitas yang sudah baik dan memadai dalam pelayanan SIM Online, yaitu media informasi yang sudha tersedia dengan berbagai bentuk dan jenis informasi (pamflet, banner, spanduk, IG (@ satlantas_sleman), website (http://sim.korlantas.polri.go.id.), Call Center Satpas Polres Sleman (02742880396), Surat Kabat dan talkshow di radio atau TV lokal. Selanjutnya fasilitas ruang tunggu yang dimiliki Satpas Polres Sleman sudah tersedia cukup nyaman dengan adanya fasilitas AC, WC, tempat bermain Anak, TV dan air minum mineral.

\section{Saran}

1. Perlu diupayakan dan diprioritaskan dalam meningkatkan kemampuan dan kualitas SDM Bagian SIM dengan pendidikan dan pelatihan khusus tentang pengelolaan SIM.

2. Sarana dan prasaran Gedung Satpas Polres Sleman belum digunakan secara optimal karena belum tersedia mabeler dan fasilitas lainnya selain ruang ujian praktek. Untuk itu disarankan agar secepatnya gedung Satpas dilengkapi dengan fasilitas yang standar dengan ketentuan dalam kelengkapan standar pelayanan Satpas.

3. Disarankan adanya penambahan perangkat komputer dan perangkat lainnya serta meningkatkan Bandwidth dengan Mbps jaringan internet yang lebih besar agar dalam pelayanan SIM Online dapat berjalan dengan lancar.

4. Perlu adanya evaluasi dan peninjauan ulang tentang tata cara Ujian Praktik karena dengan adanya kesulitan dalam ujian memungkinkan masyarakat mencari solusi lain.

\section{DAFTAR PUSTAKA}

A. Dwiyanto, 2015, Manajemen Pelayanan Publik; Peduli, Inklusif dan Kolaboratif, Yogyakarta: Gadjah Mada University Press.

Atep Adya Barata, 2014, Dasar- Dasar Pelayanan Prima, Jakarta: Elex Media Kompetindo.

Burhan Bungin, 2013, Metodologi Penelitian Sosial dan Ekonomi, Edisi Pertama, Jakarta: Prenadamedia Group.

Gregorius Chandra, dkk., 2011, Service, Quality \& Satisfaction, Edisi 3, Yogyakarta: Andi Offset.

H.A.S. Moenir, 2008, Manajemen Pelayanan Umum Di Indonesia, Jakarta: Bumi Aksara.

Harbani Pasolong, 2011, Teori Administrasi Publik, Bandung: Alfabeta.

2013, Kepemimpinan Birokrasi, Bandung: Alfabeta.

Hardiansyah, 2011, Kualitas Pelayanan Publik, Yogyakarta: Gava Media.

Mahmudi, 2010, Manajemen Kinerja Sektor Publik, Yogyakarta: UPP STIM YKPN.

Muwafik Saleh, 2010, Manajemen Pelayanan, Jakarta: Pustaka Pelajar.

Ratminto dan Atik Septi Winarsih, 2006, Manajemen Pelayanan: Pengembangan Model Konseptual, Penerapan Citizen's Charter dan Standart Pelayanan Minimal, Yogyakarta: Pustaka Pelajar.

Sinambela, dkk, 2011, Reformasi Pelayanan Publik, Jakarta: Bumi Aksara.

Soesilo Zauhar, 2007, Reformasi Administrasi, Jakarta: Bumi Aksara.

Sugiyono, 2014, Metode Penelitian Kunatitatif Kualitatif dan $R \& D$, Bandung: Alfabeta.

\section{Peraturan Perundang-Undangan}

Undang-Undang Republik Indonesia Nomor 25 Tahun 2009 tentang Pelayanan Publik.

Keputusan Menteri Pemberdayaan Aparatur Negara Nomor 63 Tahun 2003 Tentang 
Jurnal Populika, Volume 8, Nomer 1, Januari 2020

Pedoman Umum Penyelenggaraan Pelayanan Publik.

Peraturan Kepala Kepolisian Negara Republik Indonesia Nomor 9 Tahun 2012 Tentang Surat Izin Mengemudi

\section{Sumber Lainnya}

http://promoter.polri.go.id/landing/ http://sim.korlantas.polri.go.id

Tribunjogja.com: Rabu, 23 Januari 2019 